I. В. Кушкевич, С. О. Гнатуш, Г. В. Мутенко

Львівський національний університет ім. Івана Франка

\title{
АКТИВНІСТЬ КАТАЛАЗИ ТА СУПЕРОКСИДЛИСМУТАЗИ БАКTЕРIЙ DESULFOVIBRIO DESULFURICANS YA-11 ЗА ВПЛИВУ СОЛЕЙ ВАЖКИХ МЕТАЛІВ
}

Досліджено вплив $\mathrm{CdCl}_{2}, \mathrm{~Pb}\left(\mathrm{NO}_{3}\right)_{2}, \mathrm{CuCl}_{2}$ та $\mathrm{ZnCl}_{2}$ на активність каталази та супероксиддисмутази клітин Desulfovibrio desulfuricans Ya-11. Найвищу активність каталази $\left(42,67 \times 10^{-2}\right.$ мкмоль $\times \mathbf{x B}^{-1} \times \mathrm{M \Gamma}^{-1}$ білка) спостерігали за тривалої дії $\mathrm{Pb}\left(\mathrm{NO}_{3}\right)_{2}$. За дії інших солей металів вона змінюсться залежно від їх концентрації та тривалості росту. На основі результатів досліджень уперше побудовано ряд дії солей важких металів на активність каталази бактерій $\mathrm{D}$. desulfuricans Ya-11: $\mathrm{Pb}\left(\mathrm{NO}_{3}\right)_{2}>\mathrm{CuCl}_{2}>\mathrm{CdCl}_{2}>$ $\mathrm{ZnCl}_{2}$. Найвищу активність супероксиддисмутази $\left(61,52 \times 10^{2}\right.$ мкмоль $\times \mathrm{xB}^{-1} \times \mathrm{Mr}^{-1}$ білка) спостерігали за тривалого впливу $\mathrm{ZnCl}_{2}$. Інші досліджувані солі спричиняли зростання активності даного ферменту зі збільшенням концентрації солі металу. Уперше побудовано ряд дії солей важких металів на активність каталази бактерій $\mathrm{D}$. desulfuricans Ya-11: $\mathrm{ZnCl}_{2}>\mathrm{Pb}\left(\mathrm{NO}_{3}\right)_{2}>\mathrm{CuCl}_{2}>\mathrm{CdCl}_{2}$.

И. В. Кушкевич, С. А. Гнатуш, Г. В. Мутенко

Львовский национальный университет им. Ивана Франко

\section{АКТИВНОСТЬ КАТАЛАЗЫ И СУПЕРОКСИДДИСМУТАЗЫ БАКТЕРИЙ DESULFOVIBRIO DESULFURICANS YA-11 ПОД ВЛИЯНИЕМ СОЛЕЙ ТЯЖЕЛЫХ МЕТАЛЛОВ}

Исследовано влияние $\mathrm{CdCl}, \mathrm{Pb}\left(\mathrm{NO}_{3}\right)_{2}, \mathrm{CuCl}_{2}$ и $\mathrm{ZnCl}_{2}$ на активность каталазы и супероксиддисмутазы клеток Desulfovibrio desulfuricans Ya-11. Самую высокую активность каталазы $\left(42,67 \times 10^{-2}\right.$ мкмоль $\times$ мин. ${ }^{-1} \times \mathrm{Mr}^{-1}$ белка) определили при длительном действии $\mathrm{Pb}\left(\mathrm{NO}_{3}\right)_{2}$. При влиянии солей других металлов она изменяется в зависимости от их концентрации и длительности роста. На основании результатов исследований впервые определен ряд действия солей тяжелых металлов на активность каталазы бактерий $\mathrm{D}$. desulfuricans $\mathrm{Ya-11:} \mathrm{Pb}\left(\mathrm{NO}_{3}\right)_{2}>\mathrm{CuCl}_{2}>\mathrm{CdCl}_{2}>\mathrm{ZnCl}_{2}$. Самая высокая активность супероксиддисмутазы $\left(61,52 \times 10^{2}\right.$ мкмоль $\times$ мин. $^{-1} \times \mathrm{Mr}^{-1}$ белка) определена при длительном влиянии $\mathrm{ZnCl}_{2}$. Соли других тяжелых металлов вызывали увеличение активности исследуемого фермента с возрастанием их концентраций. Впервые определен ряд действия солей тяжелых металлов на активность каталазы бактерий D. desulfuricans Ya-11: $\mathrm{ZnCl}_{2}>\mathrm{Pb}\left(\mathrm{NO}_{3}\right)_{2}>\mathrm{CuCl}_{2}>\mathrm{CdCl}_{2}$.

\section{V. Kushkevych, S. O. Hnatush, H. V. Mutenko Ivan Franko Lviv National University}

\section{CATALASE AND SUPEROXIDDISMUTASE ACTIVITIES IN DESULFOVIBRIO DESULFURICANS YA-11 UNDER THE INFLUENCE OF HEAVY METALS SALTS}

The highest catalase activity $\left(42.67 \times 10^{-2} \mu \mathrm{M} \times \mathrm{min}^{-1} \times \mathrm{mg}^{-1}\right.$ of protein) in the cells of Desulfovibrio desulfuricans Ya-11 has been observed under the prolonged $\mathrm{Pb}\left(\mathrm{NO}_{3}\right)_{2}$ influence. In the presence of other heavy metals' salts it has been changed in dependence on their concentrations and growth duration. Based on our research data the row of heavy metals' salts by its influence on D. desulfuricans Ya-11 catalase acti- 
vity has been formed at first: $\mathrm{Pb}\left(\mathrm{NO}_{3}\right)_{2}>\mathrm{CuCl}_{2}>\mathrm{CdCl}_{2}>\mathrm{ZnCl}_{2}$. The highest superoxide dismutase activity $\left(61.52 \times 10^{-2} \mu \mathrm{M} \times \mathrm{min}^{-1} \times \mathrm{mg}^{-1}\right.$ of protein) has been observed under the prolonged $\mathrm{ZnCl}_{2}$ influence. In the presence of other heavy metals' salts this enzyme's activity increased with increasing the salts' concentrations. Based on our According to our results, the row of heavy metals' salts influence on $D$. desulfuricans Ya-11 superoxide dismutase activity has been formed at first: $\mathrm{ZnCl}_{2}>\mathrm{Pb}\left(\mathrm{NO}_{3}\right)_{2}>\mathrm{CuCl}_{2}>\mathrm{CdCl}_{2}$.

\section{Вступ}

Сучасний ландшафт Яворівщини сформувався внаслідок відкриття у 19561957 рр. Язівського та Немирівського родовищ самородної сірки, які експлуатувалися до 2005 року. Видобуток руди з кар'єру припинено в 1992 році через світову кризу сіркової промисловості.

Із 2002 року почалося затоплення сірчаного кар'єру на Яворівщині (Львівська область) водами річок поверхневого стоку з площі водозабору. Утворилося озеро Яворівське [3; 12]. Наявність високої концентрації органічних сполук і сульфатів спричинила розвиток сульфатвідновних бактерій у мулі Яворівського озера [7]. Ці мікроорганізми здійснюють дисиміляційне відновлення сульфатів до гідроген сульфіду, який $є$ токсичною сполукою для організмів і екологічно небезпечний для довкілля [4;5].

Бактерії Desulfovibrio desulfuricans здатні виживати при обмілінні водойм [15]. Це зумовлено наявністю у них ферментів антиоксидантного захисту, зокрема, каталази, супероксиддисмутази та пероксидазно-редуктазної системи глутатіону. Остання активується за дії токсичних сполук на клітини мікроорганізмів [17; 18].

Результати аналізу вмісту у воді іонів важких металів, зокрема $\mathrm{Cd}^{2+}, \mathrm{Zn}^{2+}, \mathrm{Pb}^{2+}$ та $\mathrm{Cu}^{2+}$, протягом декількох останніх років показали їх швидке нагромадження у придонних відкладах, що призводить до порушень функціонування мікробіоценозів [11].

Іони важких металів негативно впливають на мікроорганізми $[1 ; 6 ; 13]$. Зокрема, порушують цілісність мембран, фотосинтез, процеси трансляції [14; 16; 20], впливають на структуру та функціонування багатьох ферментів [16; 24; 27]. Проте відсутні дані про їх вплив на активність каталази та супероксиддисмутази штамів сульфатвідновних бактерій, виділених із Яворівського озера.

Мета нашої роботи - оцінити вплив хлоридів $C d^{2+}, C u^{2+}$ та $Z n^{2+}$, а також плюмбум нітрату на активність каталази та супероксиддисмутази клітин $D$. desulfuricans Ya-11.

\section{Матеріал і методи досліджень}

Об’єкт досліджень - сульфатвідновні бактерії D. desulfuricans Yа-11, виділені 3 Яворівського озера та ідентифіковані на кафедрі мікробіології Львівського національного університету ім. Івана Франка [13]. Для нагромадження біомаси бактерії D. desulfuricans Yа-11 вирощували у середовищі Постгейта С [25]. Культивування проводили за анаеробних умов протягом 8 діб при температурі $+25 \ldots+28^{\circ} \mathrm{C}$.

Із метою дослідження впливу солей важких металів на ферменти антиоксидантного захисту бактерії вирощували протягом двох діб за різних концентрацій $(0,5,1,0$, 1,5, 2,0 та 2,5 мМ) $\mathrm{CuCl}_{2}, \mathrm{CdCl}_{2}, \mathrm{~Pb}\left(\mathrm{NO}_{3}\right)_{2}, \mathrm{ZnCl}_{2}$. У контроль солей важких металів не вносили. Через кожні 24 год. відбирали клітини для подальших досліджень. Клітини відмивали від середовища 0,9 \% розчином хлориду натрію.

Безклітинні екстракти одержували, руйнуючи клітини на ультразвуковому гомогенізаторі УЗДН-2Т при 22 кГц протягом 5 хв при $0{ }^{\circ} \mathrm{C}$. Отриману суспензію переносили до центрифужних пробірок і відокремлювали безклітинний екстракт від клітинних уламків центрифугуванням при $12-15$ тис. об./хв при $4{ }^{\circ} \mathrm{C}$ протягом 30 хв на центрифузі ЦР-2. 
Концентрацію білка у безклітинних екстрактах визначали методом Лоурі [21]. Активність каталази визначали спектрофотометрично за кількістю ферментованого пероксиду гідрогену [22]. Активність супероксиддисмутази визначали за ступенем інгібування нею автоокиснення кверцетину, концентрацію якого вимірювали спектрофотометрично [9].

Основні статистичні показники вираховували за безпосередніми даними (середнє арифметичне $-M$, стандартна похибка $-m$ ). Для оцінки достовірності різниці між статистичними характеристиками сукупностей даних обраховували коефіщієнт Стьюдента. Достовірною вважалася різниця при показнику достовірності $p>0,05$ [10]. Статистичне опрацювання результатів проводили, використовуючи програми Excel та Origin [8].

\section{Результати та їх обговорення}

Солі важких металів здатні індукувати утворення активних форм кисню за дії на біологічні системи. Щоб протидіяти оксидативному стресу та знешкоджувати негативний вплив іонів важких металів, у клітинах активуються різні ланки системи антиоксидантного захисту, а саме каталаза та супероксиддисмутаза [18]. Із метою вивчення фізіолого-біохімічних характеристик доцільно дослідити функціонування цих ферментів у клітинах $D$. desulfuricans Ya-11 за умов культивування у середовищі із солями важких металів.

Активність каталази клітин Desulfovibrio desulfuricans Ya-11 за впливу солей важких металів. Каталаза - це гемумісний фермент, синтез якого активується за впливу пероксиду гідрогену. Цей фермент виявлений у клітинах еукаріот і багатьох прокаріот, зокрема у бактерій, які здійснюють відновлення сульфатів і молекулярної сірки, - Desulfotomaculum nigrificans, Desulfovibrio gigas, D. desulfuricans, D. kuznetsovii. Питома активність ферменту у цих мікроорганізмів змінюється в межах 39-189 од./мг білка [2; 24; 28]. Проте відсутні дані про зміну активності каталази бактерій $D$. desulfuricans Ya-11 за впливу солей важких металів. Тому одне із завдань роботи - оцінити активність цього ферменту протягом другої - третьої діб культивування за впливу різних концентрацій $C d C l_{2}, P b\left(N_{3}\right)_{2}$, $\mathrm{CuCl}_{2}$ та $\mathrm{ZnCl}$.

Як видно з результатів наших досліджень, за впливу $0,5 \mathrm{mM} C d \mathrm{Cl}_{2}$ на бактерії D. desulfuricans Ya-11 активність каталази зростала у 12 разів протягом другої доби культивування, але дещо зменшувалась зі збільшенням концентрації солі металу у середовищі (рис. $1 a$ ). За внесення до середовища 0,5-2,5 мM $\mathrm{CdCl}_{2}$ значення активності ферменту, порівняно з контролем, зменшувалося у 4-7 разів на третю добу (рис. 1б). Збільшення активності каталази на другу добу, очевидно, свідчить про індукцію синтезу ферменту за впливу утвореного у середовищі із хлоридом кадмію пероксиду гідрогену. Зменшення цього показника за дії 0,5-2,5 мМ $\mathrm{CdCl}_{2}$ протягом третьої доби, можливо, вказує на зниження життєздатності бактерій у зв'язку з порушенням стеричної конформації та функціональної активності білків через конкуренцію іонівкофакторів та іонів $C d^{2+}$ за транспортні системи клітини [26].

Спостерігали збільшення активності ферменту клітин $D$. desulfuricans Ya-11 за внесення солі $\mathrm{Pb}^{2+}$. Так, за впливу 2,0 мМ $\mathrm{Pb}\left(\mathrm{NO}_{3}\right)_{2}$ вона зросла у 16 разів $\left(22,85 \times 10^{-2}\right.$ мкмоль $\times \mathrm{xв}^{-1} \times \mathrm{M \Gamma}^{-1}$ білка) на другу добу (рис. $\left.1 a\right)$, та у $9-$ на третю добу вирощування (рис. 1б), порівняно з варіантом без внесення солі металу. Найбільше значення активності каталази відмітили в середовищі з $2,5 \mathrm{mM} \mathrm{Pb}\left(\mathrm{NO}_{3}\right)_{2}$ протягом третьої доби $\left(42,67 \times 10^{-2}\right.$ мкмоль $\times \mathrm{xB}^{-1} \times \mathrm{M \Gamma}^{-1}$ білка). Імовірно, значне зростання активності досліджуваного ферменту протягом двох діб культивування зумовлене утворенням значної кількості $\mathrm{H}_{2} \mathrm{O}_{2}$ за наявності солі $\mathrm{Pb}^{2+}$ та, як наслідок, зміною стеричної конформації білка 
OxyR, який унаслідок цього сприяє зв'язуванню РНК-полімерази 3 промотором, що ініціює синтез каталази, як це показано для Streptococcus faecalis [24].

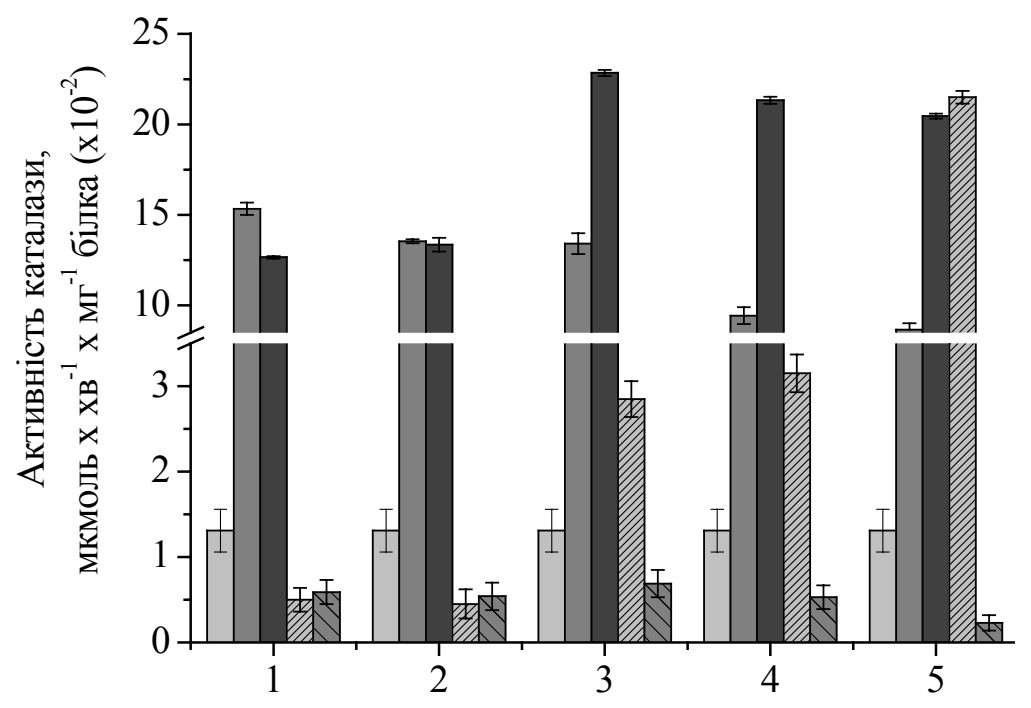

$a$

Концентрації солей металів, мМ

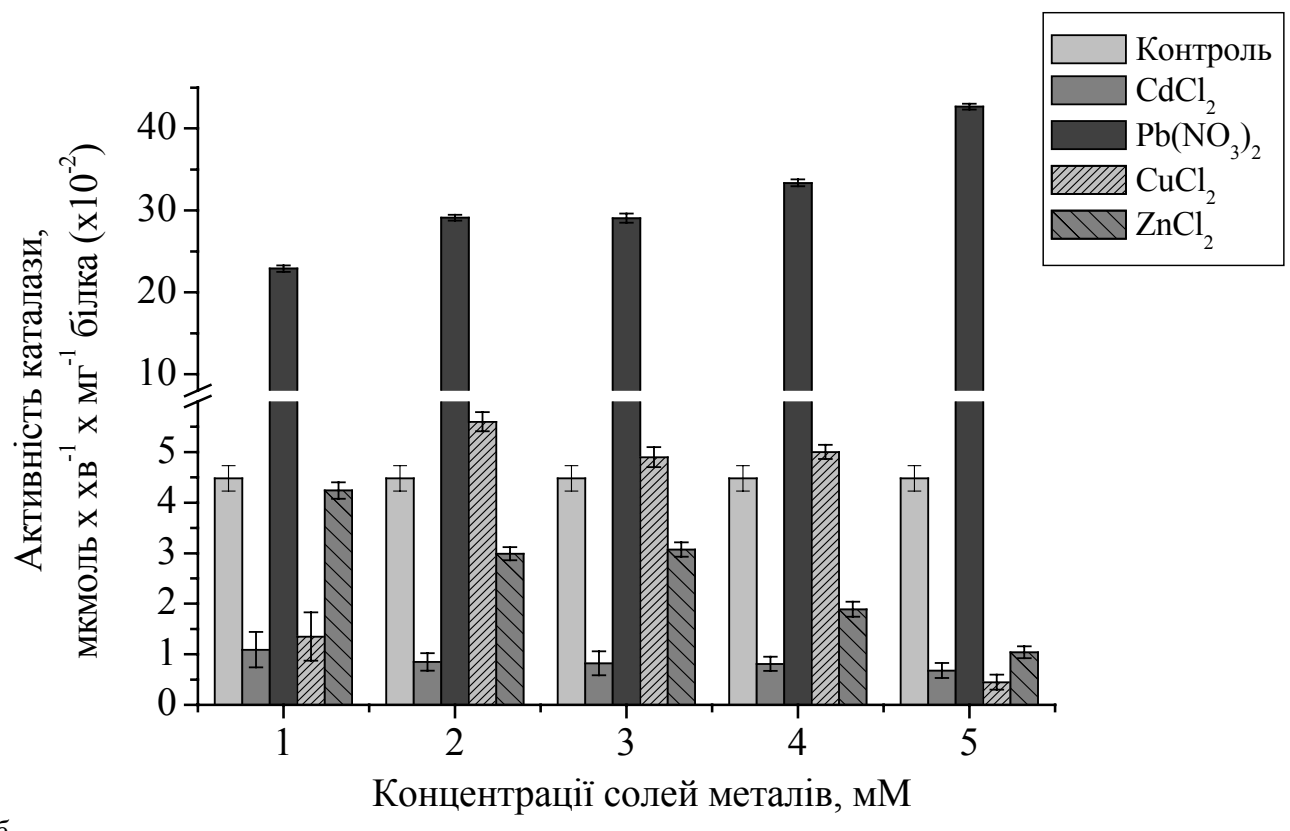

Рис. 1. Активність каталази 3 неклітинних екстрактів D. desulfuricans Ya-11 за впливу різних концентрацій солей металів: $a$ - друга доба, $\sigma$ - третя доба; $1-0,5 \mathrm{mM}, 2-1,0 \mathrm{mM}, 3-1,5 \mathrm{mM}, 4-2,0 \mathrm{MM}, 5-2,5 \mathrm{mM}$

За вмісту $0,5 \mathrm{mM} \mathrm{CuCl}_{2}$ у середовищі активність каталази клітин досліджуваних бактерій (мкмоль $\times \mathrm{xB}^{-1} \times \mathrm{M \Gamma}^{-1}$ білка) знижувалася утричі протягом другої - третьої діб вирощування, порівняно з контролем (рис. $1 a$, б). Це, ймовірно, зумовлено залученням іонів $C u$ в активні центри різних ферментів, що запобігає утворенню вільних радикалів. 
Iз подальшим зростанням концентрації солі металу активність ферменту збільшувалася. Значне зростання активності досліджуваного ферменту відмітили на другу добу вирощування за внесення $1,0-2,5$ мМ солі $C u$. На третю добу за впливу найбільшої досліджуваної концентрації $C u C l_{2}$ відбулося зменшення активності каталази у 10 разів порівняно з контролем. Такий результат, можливо, зумовлений появою в клітинах вільних радикалів за впливу значних концентрацій солі металу та їх перетворенням на пероксид гідрогену, який $є$ субстратом для каталази.

Спостерігали зниження активності каталази зі зростанням концентрації $\mathrm{ZnCl}_{2}$ протягом двох діб вирощування (рис. $1 a$, б). За вмісту $2,5 \mathrm{mM} \mathrm{ZnCl}_{2}$ активність цього ферменту зменшилася у 6-4 рази протягом другої - третьої діб культивування, порівняно 3 пробою без внесення солі металу. Найвищу активність ферменту (4,24 $\times 10^{-2}$ мкмоль $\times \mathrm{xB}^{-1} \times \mathrm{M \Gamma}^{-1}$ білка) виявили за впливу $0,5 \mathrm{MM}$ солі металу на третю добу.

Таким чином, найвищу активність каталази визначено у середовищі з $\mathrm{Pb}\left(\mathrm{NO}_{3}\right)_{2}$. Очевидно, сіль цього металу спичиняе утворення великої кількості пероксиду гідрогену. Низька активність досліджуваного ферменту при тривалому витримуванні бактерій із $\mathrm{ZnCl}_{2}$, імовірно, зумовлена його низькою оксидантною активністю, порівняно з іншими досліджуваними солями металів, та залученням цих іонів у активні центри деяких ферментів, що задіяні у процесах гліколізу, синтезу цитохромів, порфіринів, гемопротеїнів, $i$ РНК. Визначена активність каталази досліджуваного штаму бактерій була низькою, порівняно з іншими штамами бактерій роду Desulfovibrio. Це, ймовірно, зумовлює чутливість бактерій Desulfovibrio desulfuricans Ya-11 до окисного стресу, який виникає в клітинах за дії солей важких металів. Очевидно, для нейтралізації негативного впливу цього чинника мікроорганізми синтезують глутатіон, вміст якого буде визначено в нашій наступній роботі. На основі результатів досліджень побудовано ряд дії солей важких металів на активність каталази бактерій Desulfovibrio desulfuricans Ya-11: $\mathrm{ZnCl}_{2}<\mathrm{CdCl}_{2}<\mathrm{CuCl}_{2}<\mathrm{Pb}\left(\mathrm{NO}_{3}\right)_{2}$.

Наші результати узгоджуються 3 даними літератури [20; 27], які вказують на збільшення активності каталази бактерій за впливу солей важких металів.

Активність супероксиддисмутази клітин D. desulfuricans Ya-11 за виливу солей важких металів. Супероксиддисмутаза - металумісний фермент, який нейтралізує супероксиданіон-радикал. У складі різних ізоформ цього білка виявлено іони $\mathrm{Fe}, \mathrm{Zn}, \mathrm{Cu}$, $M n$. Цей ензим виявлений у клітинах бактерій різних фізіологічних груп. Серед мікроорганізмів, які забезпечують кругообіг $S$ у природі, супероксиддисмутазу ідентифіковано у Desulfotomaculum nigrificans, Desulfovibrio gigas, D. desulfuricans, D. vulgaris, Chlorobium thiosulfatophilum, Chromatium sp. Ï̈і активність у цих бактерій коливається в межах 1-14 одиниць на 1 мг білка [2; 18; 19]. Такі показники активності визначені за умов відсутності стресових чинників. Проте немає даних про активність супероксиддисмутази бактерій $D$. desulfuricans Ya-11 за дії солей важких металів.

За внесення $\mathrm{CdCl}_{2}$ активність супероксиддисмутази зростала порівняно з контролем (утричі за впливу $0,5 \mathrm{mM} \mathrm{CdCl}$ ), але майже не змінювалась зі збільшенням концентрації солі металу протягом другої доби культивування (рис. $2 a$ ). Протягом третьої доби вирощування у середовищі із сіллю цього металу активність зменшувалася. Найбільше іiі значення $\left(10,58 \times 10^{2}\right.$ мкмоль $\times \mathrm{xB}^{-1} \times \mathrm{M \Gamma}^{-1}$ білка) встановили за дії $1,0 \mathrm{MM} \mathrm{CdCl}_{2}$ протягом другої доби вирощування (рис. 2a). Очевидно, збільшення активності супероксиддисмутази в середовищі з $\mathrm{CdCl}_{2}$ зумовлене появою захисної відповіді бактерій на дію токсичних іонів. Значне зменшення активності досліджуваного ферменту на третю добу, порівняно 3 другою, ймовірно, спричинене сильним порушенням процесів клітинного 
метаболізму внаслідок денатурації білків, пригніченням дихання шляхом зв'язування сульфгідрильних груп ферментів, мутагенною дією солі металу [16; 19].

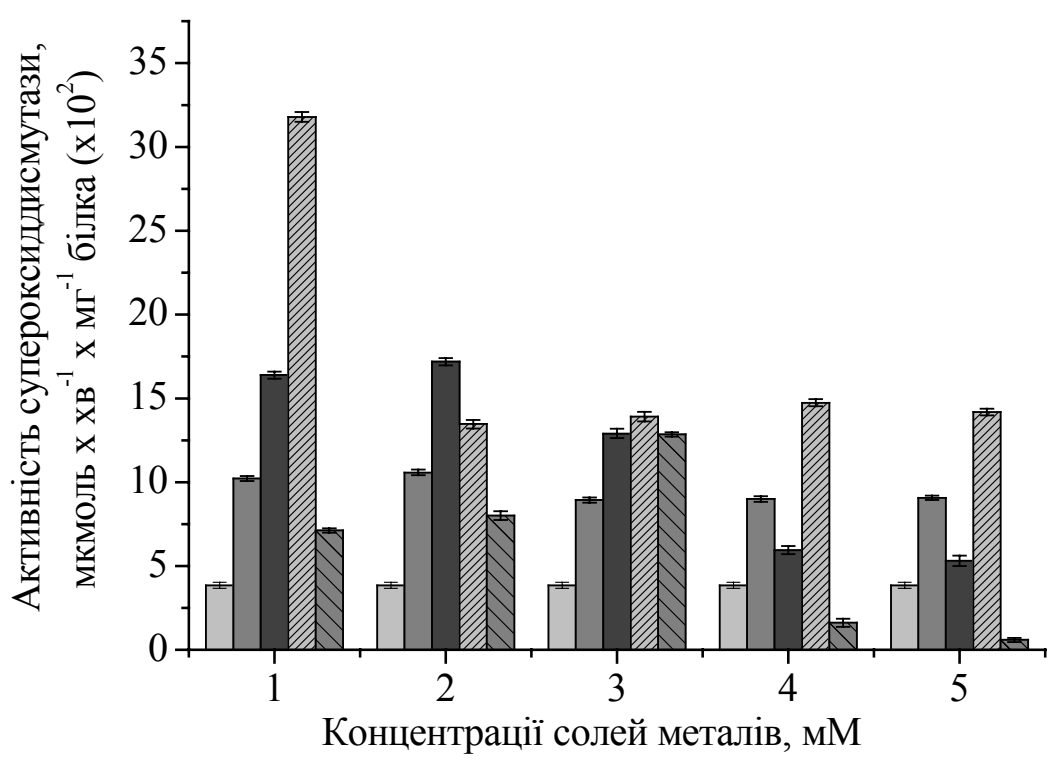

a

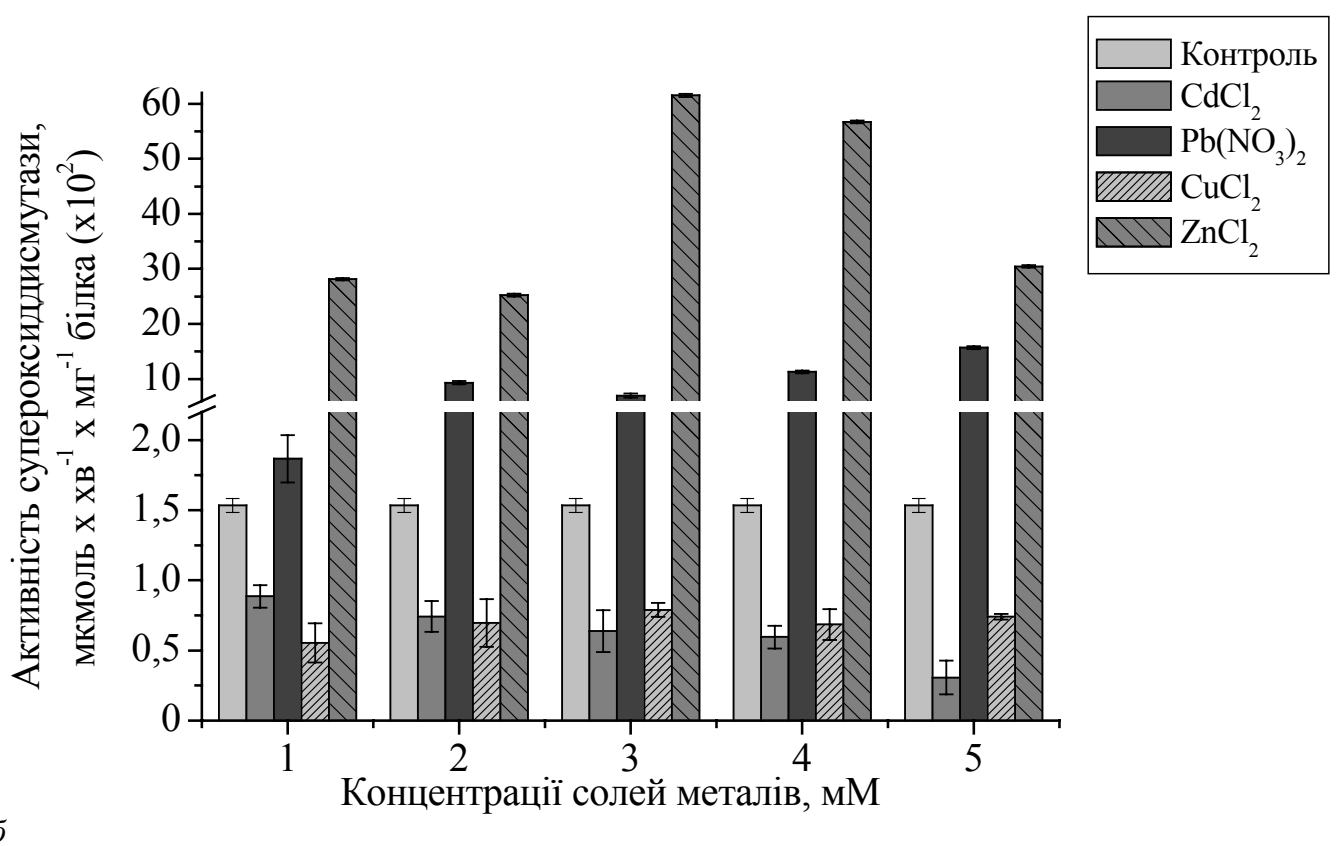

Рис. 2. Активність супероксиддисмутази з неклітинних екстрактів D. desulfuricans Ya-11 за впливу різних концентрацій солей металів: $a$ - друга доба, $\sigma$ - третя доба; $1-0,5 \mathrm{MM}, 2-1,0 \mathrm{MM}, 3-1,5 \mathrm{MM}, 4-2,0 \mathrm{MM}, 5-2,5 \mathrm{mM}$

Протягом двох діб культивування за внесення у середовище $\mathrm{Pb}\left(\mathrm{NO}_{3}\right)_{2}$ активність ферменту збільшувалась порівняно з контролем. На другу добу активність супероксиддисмутази була вищою за впливу незначних концентрацій солі $P b$ (зросла учетверо при $0,5-1,0$ мM) (рис. 2a). Протягом третьої доби культивування бактерій 30 
D. desulfuricans Yа-11 активність ферменту збільшувалась зі зростанням досліджуваних концентрацій солі металу (рис. 26). Можливо, збільшення активності супероксиддисмутази при внесенні солі металу зумовлене індукцією іiі експресії soxRSрегулону або безпосередньо іонами ксенобіотика, або внаслідок появи в клітинах супероксиданіону [23]. Внаслідок тривалого культивування за присутності солі $P b$, очевидно, пригнічуються процеси клітинного метаболізму через пошкодження ультраструктури мембран і органел [26] і знижується активність супероксиддисмутази, тому на третю добу середнє значення цього показника є меншим, порівняно з другою.

Внесення $\mathrm{CuCl}_{2}$ спричиняло зростання активності ферменту на другу добу культивування та ії зниження протягом третьої доби вирощування, порівняно з контролем (рис. $2 a$, б). Найвищу активність ферменту $\left(31,80 \times 10^{2}\right.$ мкмоль $\times \mathrm{xB}^{-1} \times \mathrm{M \Gamma}^{-1}$ білка) спостерігали за впливу $0,5 \mathrm{mM} \mathrm{CuCl}_{2}$ на другу добу вирощування бактерій. Очевидно, збільшення активності ферменту зумовлене залученням іонів $C u$ до його складу як кофактора, що безпосередньо забезпечує здійснення дисмутації супероксиданіону. Зниження цього показника за тривалого культивування бактерій із хлоридом металу, ймовірно, спричинене його токсичним впливом на клітину, що виявляєтья в пригніченні метаболічних процесів у зв'язку з інактивацією ферментів ( $\alpha$-кетоглутаратдегідрогенази), порушенням інтактності та збільшенням проникності клітинної стінки [2; 26]. Зниження активності супероксиддисмутази з порівняно низькою активністю каталази за тривалої дії $\mathrm{CuCl}_{2}$, можливо, спричинене генеруванням у клітині реакцій Фентона за умов утворення та недостатньої нейтралізації $\mathrm{H}_{2} \mathrm{O}_{2}$, який є продуктом каталізу супероксиддисмутази.

За наявності $\mathrm{ZnCl}_{2}$ активність ферменту зменшувалась протягом другої доби, але зростала на третю, порівняно $з$ контролем (рис. $2 a$, б). Найвищу активність супероксиддисмутази $\left(61,52 \times 10^{2}\right.$ мкмоль $\times \mathrm{xB}^{-1} \times \mathrm{M \Gamma}^{-1}$ білка) спостерігали за дії $1,5 \mathrm{MM} \mathrm{ZnCl} l_{2}$ на третю добу культивування. Очевидно, ії збільшення на третю добу зумовлене залученням цих іонів до складу ферменту як кофактора, який стабілізує супероксиддисмутазу, або генеруванням активних форм кисню за дії $Z n^{2+}$. За нетривалого впливу, ймовірно, генерується пероксидазно-редуктазна система глутатіону, яка забезпечує зв'язування іонів $Z n$. За тривалої дії стресового чинника активність цієї системи знижується $\mathrm{i}$, очевидно, тому збільшується активність супероксиддисмутази [16].

Таким чином, найвищу активність супероксиддисмутази виявили за впливу солей $P b$ та $Z n$. Очевидно, це свідчить про генерацію стану сильного окисного стресу за дії $\mathrm{Pb}\left(\mathrm{NO}_{3}\right)_{2}$, порівняно 3 іншими досліджуваними солями металів. Значна активність ферменту за наявності у середовищі іонів $Z n$, ймовірно, зумовлена залученнням цих іонів до складу ферменту як кофактора та стабілізацією ферменту. Значення активності супероксиддисмутази, одержані у нашій роботі для D. desulfuricans Ya-11, виявились більшими, порівняно $з$ даними літератури $[2 ; 18 ; 19 ; 23 ; 26]$. Очевидно, це зумовлено штамоспецифічністю структури та функцій даного ферменту. Побудовано ряд дії солей важких металів на активність супероксиддисмутази бактерій D. desulfuricans Ya-11: $\mathrm{ZnCl}_{2}>\mathrm{Pb}\left(\mathrm{NO}_{3}\right)_{2}>\mathrm{CuCl}_{2}>\mathrm{CdCl}_{2}$.

\section{Висновки}

Найвищу активність каталази $\left(42,67 \times 10^{-2}\right.$ мкмоль $\times \mathrm{xB}^{-1} \times \mathrm{M \Gamma}^{-1}$ білка) спостерігали за тривалої дії $\mathrm{Pb}\left(\mathrm{NO}_{3}\right)_{2}$. За дії інших солей металів вона змінюється залежно від їх концентрації та тривалості росту. На основі результатів досліджень побудовано ряд дії солей важких металів на активність каталази бактерій $D$. desulfuricans Ya-11: $\mathrm{Pb}\left(\mathrm{NO}_{3}\right)_{2}>$ $\mathrm{CuCl}_{2}>\mathrm{CdCl}_{2}>\mathrm{ZnCl}_{2}$. 
Найвищу активність супероксиддисмутази $\left(61,52 \times 10^{2}\right.$ мкмоль $\times \mathrm{xB}^{-1} \times \mathrm{M \Gamma}^{-1}$ білка) спостерігали за тривалого впливу $\mathrm{ZnCl}_{2}$. Інші солі досліджуваних металів спричиняли зростання активності цього ферменту зі збільшенням концентрації солі металу. Побудовано ряд дії солей важких металів на активність каталази бактерій $D$. desulfuricans Ya-11: $\mathrm{ZnCl}_{2}>\mathrm{Pb}\left(\mathrm{NO}_{3}\right)_{2}>\mathrm{CuCl}_{2}>\mathrm{CdCl}_{2}$.

\section{Бібліографічні посилання}

1. Авакян 3. А. Сравнительная токсичность тяжелых металлов для некоторых микроорганизмов // Микробиология. - 1967. - Т. 36, № 3. - С. 445-450.

2. Брюханов А. Л. Каталаза и супероксиддисмутаза: распространение, свойства и физиологическая роль в клетках строгих анаэробов / А. Л. Брюханов, А. И. Нетрусов // Биохимия. - 2004. T. 69. - С. 1170-1186.

3. Гайдін А. М. Яворівське озеро / А. М. Гайдін, І. І. Зозуля. - Львів : Інститут гірничо-хімічної промисловості, 2007. - 70 с.

4. Громов Б. В. Экология бактерий / Б. В. Громов, Г. В. Павленко. - Л. : Ленинградский ун-т, 1989. $-248 \mathrm{c}$.

5. Галушка А. А. Вплив гідроген сульфіду на Escherichia coli / А. А. Галушка, Т. Б. Перетятко, С. П. Гудзь // Вісн. Львів. ун-ту. Сер. біол. - 2008. - Вип. 48. - С. 129-134.

6. Грузина Т. Т. Изучение ингибирующего влияния ионов свинца на клетки некоторых штаммов бактерий рода Pseudomonas / Т. Т. Грузина, Т. П. Чеховская, М. Н. Баланина // Укр. біохім. журн. - 2002. - Т. 74, № 2. - С. 115-119.

7. Динаміка змін титру сульфатвідновлювальних бактерій та вмісту сульфатів і сірководню у водах кар'єру Яворівського сіркового родовища в процесі його затоплення / С. П. Гудзь, С. О. Гнатуш, Т. Б. Перетятко та ін. // Вісн. Львів. ун-ту. Сер. біол. - 2004. - Вип. 37. - С. 185-189.

8. Исакова О. П. Обработка и визуализация данных физических экспериментов с помощью пакета Origin / О. П. Исакова, Ю. Ю. Тарасевич, Ю. И. Юзюк. - М. : Либком, 2009. - 136 с.

9. Костюк В. А. Простой и чувствительный метод определения активности супероксиддисмутазы, основанный на реакции окисления кверцетина / В. А. Костюк, А. И. Потапович, Ж. В. Ковалева // Вопросы медицинской химии. - 1990. - Т. 36, № 2. - С. 88-91.

10. Лакин Г. Ф. Биометрия. - М. : Высш. шк., 1990. - 352 с.

11. Вплив важких металів на ріст та відновлення сульфатів Desulfovibrio desulfuricans / О. М. Мороз, С. П. Гудзь, О. І. Подопригора та ін. // Наук. вісн. Ужгородського ун-ту. Серія Біологія. 2009. - Вип. 26. - С. 193-202.

12. Мікрофлора води озера Яворівське / О. М. Мороз, Я. І. Колісник, О. І. Подопригора та ін. // Наук. вісн. Ужгородського ун-ту. Серія біологія. - 2008. - Вип. 24. - С. 131-138.

13. Перетятко Т. Б. Екологічне значення сульфатвідновлювальних бактерій штучних водойм (на прикладі Яворівського родовища сірки): Автореф. дис. ... канд. біол. наук: 03.00.16. - К. , 2007. - 140 с.

14. Abbas A. Effects of metals on a range of Streptomyces species / A. Abbas, C. Edwards // Applied and Environmental Microbiology. - 1989. - Vol. 55. - P. 2030-2035.

15. Abdollahi H. Effects of oxygen on the growth of Desulfovibrio desufiuricans / H. Abdollahi, J. W. Wimpenn // J. of General Microbiology. - 1990. - Vol. 136. - P. 1025-1030.

16. Byeong C. J. Localization of enzymically enhanced heavy metal accumulation by Citrobacter $s p$. and metal accumulation in vitro by liposomes containing entrapped enzyme / C. J. Byeong, C. Hawes, K. M. Bonthrone // Microbiology. - 1997. - Vol. 143. - P. 2497-2507.

17. Chen K. Zinc activates the ARE - dependent antioxidant response in the RPE / K. Chen, J. Cai, P. Strenberg // Ophtalmology. - Nashville, TN: Vanderbilt University School of Medicine, 2006.

18. Fournier M. Function of oxygen resistance proteins in the anaerobic, sulfate-reducing Bacterium desulfovibrio vulgaris Hildenborough / M. Fournier, Y.Zhang, J. D. Wildschut // J. of Bacteriology.2003. - Vol. 185. - P. 71-79.

19. Fridopvich I. Oxygen toxicity and the superoxide dismutase / I. Fridopvich, E. M. Gregory // J. of Bacteriology. - 1973. - Vol. 114. - P. 1193-1197. 
20. Gadd G. M. Metals and microorganisms: A problem of definition // FEMS Microbiol. Letts. - 1992. Vol. 100. - P. 197-204.

21. Protein determination with the folin phenol reagent / O. H. Lowry, N. J. Rosebrough, A. L. Farr, R. J. Randall // J. Biol. Chem. - 1951. - Vol. 193. - P. 265-275.

22. Luck H. Catalase // Methods in enzymatic analysis / H.-U. Bergmeyer ed. - London : Academic Press, 1963. - P.855-894.

23. McCormick M. L. Endogenous superoxide dismutase levels regulate iron-dependent hydroxyl radical formation in Escherichia coli exposed to hydrogen peroxide / M. L. McCormick, G. R. Buettner, B. E. Britigan // J. of Bacteriology. - 1998. - Vol. 180. - P. 622-625.

24. Niven C. F. Catalase activity of two Streptococcus faecalis strains and its enhancement by aerobiosis and added cations // J. of Bacteriology. - 1964. - Vol. 88. - N 3. - P. 602-610.

25. Postgate J. R. The sulfate-reducing bacteria. - Cambridge : Cambridge University Press, 1984. $-208 \mathrm{p}$.

26. Stuczynski T. I. Response of soil microbiological activities to cadmium, lead, and zinc salt amendments / T. I. Stuczynski, G. W. McCarty, G. Siebielec // J. Environ. Qual. - 2003. - Vol. 32. P. 1346-1355.

27. Tejada M. Application of two organic wastes in a soil polluted by lead: Effects on the soil enzymatic activities / M. Tejada, M. T. Hernandes, C. Garcia // J. Environ. Qual. - 2007. - Vol. 36. - P. 216-225.

28. Xavier A. V. Purification and characterization of an iron superoxide dismutase and a catalase from the sulfate-reducing bacterium Desulfovibrio gigas // J. of Bacteriology. - 2000. - Vol. 182. - P. 796-804.

Надійшла до редколегії 21.06.2010 